\title{
A COMPARISON OF SCIENCE INTEGRATION IMPLEMENTATION IN TWO STATE ISLAMIC UNIVERSITIES IN INDONESIA
}

\author{
Wahdi Sayuti', Maila D.H. Rahiem² \\ 1,2 State Islamic University (UIN) of Syarif Hidayatullah Jakarta \\ Jl. Ir. H. Djuanda No. 95 Ciputat 15412 \\ Email: 1wahdisayuti@uinjkt.ac.id; 2mailadinia@uinjkt.ac.id
}

\begin{abstract}
The transformation of IAIN (State Institute for Islamic Studies) into UIN (State Islamic University) cannot be isolated from discourses on identity, concepts, aspirations of the standard of Islamic education and its goal to incorporate the principle of integration of science. However, since the transformation of these institutions, the integration of science practice still appears at the normative-philosophical level and is not yet in the empiricalimplementation domain. The aim of this study is, therefore, to reveal and explain the implementation of the integration of the science concept at the technical-operational level, which focuses on the curriculum design and learning process at UIN Syarif Hidayatullah Jakarta and UIN Maulana Malik Ibrahim Malang. The results of the study showed that these two universities have similarities in the concept of the integration of science and have almost the same objectives, i.e., decreasing the dichotomy of science between religious and general science. However, UIN Maulana Malik Ibrahim Malang has a more organized and structured approach to the idea of integration, from theory and framework to the practice of curriculum design and the learning process.
\end{abstract}

Keywords: science integration; curriculum design; learning process.

\begin{abstract}
Abstrak: Perubahan status kelembagaan dari Institut Agama Islam Negeri (IAIN) menjadi Universitas Islam Negeri (UIN) tidak bisa dilepaskan dari diskursus tentang identitas, gagasan, ekspektasi terhadap mutu lembaga pendidikan Islam dan sekaligus mengemban misi tentang pentingnya integrasi keilmuan. Namun demikian, sejak perubahan status kelembagaan ini, integrasi keilmuan yang dikembangkan di UIN ini nampaknya masih berada pada tataran normatif-filosofis dan belum menyentuh wilayah yang lebih empirik-implementatif. Oleh karenanya, penelitian ini bertujuan untuk mengungkap dan menjelaskan implementasi integrasi keilmuan ke dalam tataran yang lebih teknis operasional, yang dalam penelitian ini difokuskan pada pengembangan kurikulum dan proses pembelajaran di UIN Syarif Hidayatullah, Jakarta dan UIN Maulana Malik Ibrahim, Malang. Hasil penelitian menunjukkan bahwa secara substantif, kedua perguruan tinggi Islam memiliki kemiripan konsep integrasi keilmuan dan memiliki tujuan yang hampir sama, yakni menghilangkan dikotomi keilmuan, antara ilmu agama dan ilmu umum. Namun, jika dibandingkan antara UIN Syarif Hidayatullah Jakarta dan UIN Maulana Malik Ibrahim Malang, maka UIN Maulana Malik Ibrahim Malang dinilai lebih terencana dan sistematis dalam merumuskan konsep integrasi keilmuannya, dari mulai perumusan konsep dan paradigma sampai pada operasionalisasi penyusunan kurikulum dan proses pembelajaran.
\end{abstract}

Kata kunci: integrasi keilmuan; desain kurikulum; proses pembelajaran.

\section{Introduction}

The discourse of science integration is one of the biggest agendas in the institutional transformation of several State Islamic Higher Education (PTKIN) institutions in Indonesia, especially since PTKIN has transformed the State Institute for Islamic Studies (IAIN) to become the State Islamic University (UIN). ${ }^{1}$ The major

${ }^{1}$ The first discourse of the Islamization of science was project of science integration in the context of

raised by al-Attas and al-Faruqi in 1977 at a world conference held in Mecca at the initiative of King Abdul Aziz University. Al-Attas discussed the Islamization of science to overcome the conflict between value-free modern science and Islamic sciences. Al-Faruqi also presented a paper entitled "Islamicizing Social Science." See. Muhaimin, Arah Baru Pengembangan Pendidikan Islam; Pemberdayaan, Pengembangan Kurikulum, hingga Redefinisi Islamisasi Pengetahuan, (Bandung: Penerbit Nuansa, 2003), p. 31-32. Today, several Islamic Higher Educations in Indonesia, especially UIN throughout Indonesia are developing an integrative paradigm in Islamic sciences. 
PTKIN's transformation, is considered as one of the identities and distinguishing features of the institution, even an identity that distinguishes between universities under the coordination of the Ministry of Religious Affairs and universities under the coordination of the Ministry of Education and Culture. In addition, the integration of science is also supposed to bring the scientific identity back that is not happening currently due to the dichotomy between general and religious sciences. ${ }^{2}$

Mulyadi emphasized that the dichotomy of science into religious and non-religious sciences is actually not something new. ${ }^{3}$ Islam has had this dichotomic tradition for more than a thousand years. However, the dichotomy did not give rise to the Islamic education system problems, until the Western-secular education system was introduced to the Islamic world through imperialism. ${ }^{4}$ Several factors causing the scientific dichotomy are the differences in the aspects of ontology, epistemology and axiology. As it is known that religion (Islamic) sciences are sourced from revelation that is absolutely true and is assisted by reasoning, which in the implementation process must not contradict with revelation. ${ }^{5}$ Meanwhile, the general science that has come from the West has been based on an atheistic, materialistic, secularistic, empiricistic, rationalistic, even hedonistic philosophical view. ${ }^{6}$ The two ideas of the backgrounds of these two

See. Umi Hanifah. "Islamisasi IImu Pengetahuan Kontemporer (Konsep Integrasi Keilmuan di Universitas-Universitas Islam Indonesia)", Tadris, vol. 13, no.2, Desember 2018. https://doi. org/10.19105/tjpi.v13i2.1972

${ }^{2}$ M. Amin Abdullah, "Religion, science and culture: An integrated, interconnected paradigm of science, " Al-Jami'ah, vol. 52, no 1 (2014), https://doi.org/10.14421/ajis.2014.521.175203

${ }^{3}$ Rz Ricky Satria Wiranata, "Jalan Tengah: Kritik Paradigma Pendidikan di Barat (Sebuah Kajian Filosofis Historis)." AlMisbah (Jurnal Islamic Studies), vol.8. no. 2 (2020), pp. 86-93.

${ }^{4}$ Mulyadi Kertanegara, Integrasi Ilmu: sebuah Rekonstruksi Holistik, (Bandung: Arasy, 2005), First Edition, pp. 19. See. Also. Syarif Hidayatullah, "Islamisasi Ilmu dalam Perspektif Filsafat Ilmu." Jurnal Filsafat, vol. 23no. 3 (2013), pp. 233-251.

5 Al-Faruqi, Isma'il Razi, Al-Tauhid: Its Implications for Thought and Life, The International Institute of Islamic Thought, Virginia-USA, 1992.

6 Nurlena Rifa'i, et.al., “Integrasi Keilmuan dalam Pengembangan Kurikulum di UIN se-Indonesia", TARBIYA: Jurnal of Education in Muslim Society, vol. 1, no. 1 ( June 2014), pp. 13 sciences are clearly very different, and difficult to integrate together. ${ }^{7}$

In the context of eliminating the dichotomy or integrating between religious and general sciences, science integration is required or as Azyumardi Azra described it, the reintegration of sciences. ${ }^{8}$ But in the context of science integration, according to Mulyadi, it is not possible to achieve it by only integrating two scientific clusters that have different theoretical bases (secular and religious). This integration (or reintegration) must be pursued to the epistemological level. Combining the two different scientific clusters, secular and religious, in an educational institution, as has happened all this time, without being accompanied by epistemological construction is the experimentation that will not bring about the integration, but will only lead to these two entities running side by side, but independently of each other. To achieve an epistemological integrity, integration must be conducted at several aspects or levels, which includes ontological integration, integration of the classification of science and integration of methodology. ${ }^{9}$

The plan to clear up this dichotomy is one of the reasons behind the creation of several UINs in Indonesia, including UIN Syarif Hidayatullah Jakarta and UIN Maulana Malik Ibrahim Malang. The existence of these two UINs is a metamorphosis of the previous institutions, IAIN Syarif Hidayatullah Jakarta and STAIN Malang, although they are both carrying the same mission, which is to integrate sciences between religious and general sciences. However, when examining the progress, the main agenda of science integration in the two UINs seems to be

${ }^{7}$ Azra, Azyumardi, Pendidikan Islam: Tradisi dan Modernisasi Menuju Milenium Baru [Islamic Education: Tradition and Modernisation In the New Millennium], (Jakarta: Logos Wacana IImu, 2002). See. Also. Abuddin Nata, et.al., Integrasi IImu Agama dan Ilmu Umum, (Jakarta: PT. Raja Grafindo Persada, 2005), First Edition, pp. 4

${ }^{8}$ Lalu Muhammad Nurul Wathan, Integrasi Pendidikan Islam dan Sains: Rekonstruksi Paradigma Pendidikan Islam, (Ponorogo: CV. Uwais Inspirasi Indonesia, 2018), pp. 209

9 Mulyadi Kertanegara, Integrasi Ilmu: sebuah Rekonstruksi..., pp. 208 - 209. Futhermore, Kuntowijoyo explained that Islam comes not only as a science that offers epistemology and methodology, but also ethics. See. Kuntowijoyo, Islam Sebagai Ilmu: Epistimologi, Metodologi dan Etika, (Yogyakarta: Tiara Wacana, 2007), pp.. 50-51 
stagnant. ${ }^{10}$ Only in the creation and establishment of the general study program does there seem to have been any real significant development, although the systematic efforts to reintegrate the sciences appear only at the normativephilosophical level and not yet in the empiricalimplementation domain. ${ }^{11}$

The very important aspect in the context of applying science integration at UIN is translating the concept of science integration into the learning management system, which is manifested in curriculum design and learning processes, ${ }^{12}$ because both are very strategic instruments to enable the concept of science integration to occur, so that the concept not only stands in a philosophical position, but also enters in a systematic, hierarchical, and measurable way into the curriculum design and learning processes. However, to analyze the concept of science integration in curriculum development and the learning process, of course, depends on the paradigm, policy and formulation of the science integration concept in each UIN, because both UINs have autonomy in formulating the concept of science integration based on the academic domain and contextualization within each university's individual environment. ${ }^{13}$

Based on the different paradigms, policies, and formulations of science integration concepts in the two UINs, this study will describe and analyze the implementation of science integration into the learning management system, starting from curriculum design to learning practices. This analysis is hoped to provide the description of both UINs in the context of translating the concept of

10 Umi Hanifah, "UPAYA INTEGRASI DIKOTOMI SISTEM PENDIDIKAN ISLAM (Telaah Terhadap Islamisasi Ilmu Pengetahuan dalam Transformasi IAIN Menuju UIN)", AtTajdid: Jurnal Ilmu Tarbiyah, vol.1, no. 1 (2012), pp.19-35

"Luthfi Hadi Aminuddin, "INTEGRASI ILMU DAN AGAMA: Studi Atas Paradigma Integratif Interkonektif UIN Sunan Kalijaga Yogjakarta," Kodifikasia, vol.4.no.1 (2010), pp.1-34

${ }_{12}$ Nurlena Rifai,et,al, Integrasi Keilmuan dalam Pengembangan..., pp. 13-33

13 Parluhutan Siregar, "Integrasi IImu-IImu Keislaman Dalam Perspektif M.Amin Abdullah” MIQOT: Jurnal IImu-Ilmu Keislaman. vol. XXXVIII, no. 2 (Juli-Desember 2014), See. Nur Jamal, " Model-Model Integrasi Keilmuan Perguruan Tinggi Keagamaan Islam" , KABILAH : Journal of Social Community 2, no. 1 (October 13, 2017), pp. 83-101. http://ejournal.kopertais4. or.id/madura/index.php/kabilah/article/view/3088 science integration from normative-philosophical into technical-implementative domain. Moreover, the results of this study are expected to be a role model in the operationalization of the science integration concept into learning management, as well as being an input for policy holders in the Ministry of Religious Affair and the leaders of PTKIN who will transform their institutions from IAIN into UIN.

\section{Method}

This study uses evaluative research, which is the type of research that aims to evaluate and find answers about achieving the goals planned earlier. In this context, two approaches were used, the qualitative approach and the quantitative approach. Qualitative data was obtained from interviews with key informants, a document review, and class observations. The results of interviews from key informants were used as the main source in this study, followed by the data stages including data collection, data reduction, data display and data verification/ conclusion. The quantitative data was obtained from the results of the questionnaires that were distributed to the lecturers and students displayed in the tables related to the implementation of science integration in the learning process.

\section{Result and Discussion Paradigm and Concept}

The concept and paradigm of the science integration developed at UIN Jakarta and UIN Malang, substantially refer to the same point, that is eliminating the dichotomy between the truth of revelation and the truth of science. The empirical truth of science is actually in line with the truth of transcendental revelation. In other words, the concepts and paradigms of science integration at the two universities actually want to combine the truth of revelation (religion) with the truth of science in an educational forum. However, the concept of science integration in each UIN has editorial diversity and elaboration that is very contextual within the specific environment of each university. The following is an illustration of the concept of science integration at UIN Syarif Hidayatullah Jakarta and UIN Maulana Maik 
Ibrahim Malang based on the scientific paradigm developed.

Table 1. Paradigm and Concept of the Science integration

\begin{tabular}{|c|c|c|c|}
\hline No & $\begin{array}{l}\text { Name of } \\
\text { University }\end{array}$ & Paradigm & Concept \\
\hline 1 & $\begin{array}{l}\text { UIN Syarif } \\
\text { Hidayatullah } \\
\text { Jakarta }\end{array}$ & $\begin{array}{l}\text { Islam does not } \\
\text { recognize the } \\
\text { dichotomy of } \\
\text { science, because } \\
\text { the source of all } \\
\text { knowledge is God. } \\
\text { Therefore, the } \\
\text { scientific paradigm } \\
\text { developed is to } \\
\text { bring science } \\
\text { together with the } \\
\text { truth of revelation }\end{array}$ & $\begin{array}{l}\text { The integration } \\
\text { of science is a } \\
\text { unification of } \\
\text { religious science } \\
\text { and general science, } \\
\text { as well as an } \\
\text { integration between } \\
\text { religious science } \\
\text { and general science. } \\
\text { This combination } \\
\text { includes three } \\
\text { aspects; ontological } \\
\text { integration, science } \\
\text { classification } \\
\text { integration and } \\
\text { methodological } \\
\text { integration. The } \\
\text { integration is a } \\
\text { dialogic substance } \\
\text { in the context of } \\
\text { integration, which is } \\
\text { that the integration } \\
\text { is basically a } \\
\text { reintegration of } \\
\text { science processes, } \\
\text { which includes } \\
\text { dialogical integration } \\
\text { attributes, integrative } \\
\text { or the Islamization of } \\
\text { science. }\end{array}$ \\
\hline 2 & $\begin{array}{l}\text { UIN Maulana } \\
\text { Malik Ibrahim, } \\
\text { Malang }\end{array}$ & $\begin{array}{l}\text { Islam assigns } \\
\text { religion as the basis } \\
\text { of knowledge. Al- } \\
\text { Qur'an and Al-Hadis } \\
\text { in the development } \\
\text { of science are } \\
\text { positioned as } \\
\text { sources of qauliyyah } \\
\text { verses. As for the } \\
\text { observation results, } \\
\text { experimentation } \\
\text { and logical thinking } \\
\text { are positioned } \\
\text { as sources of } \\
\text { kauniyyah verses. } \\
\text { With this position, } \\
\text { various components } \\
\text { of knowledge can } \\
\text { always be searched } \\
\text { from the Qur'an } \\
\text { and the Hadith. } \\
\text { The metaphor } \\
\text { used is "a Sturdy } \\
\text { Tree", which has } \\
\text { boughs, is leafy, } \\
\text { and fruitful because } \\
\text { it is supported } \\
\text { by strong roots. } \\
\text { Strong roots not } \\
\text { only serve to } \\
\text { support the tree's } \\
\text { trunk, but also } \\
\text { absorb soil content } \\
\text { for the tree's } \\
\text { growth. }\end{array}$ & $\begin{array}{l}\text { The integration } \\
\text { of science is a } \\
\text { unification of } \\
\text { religious and general } \\
\text { science in one unit. } \\
\text { The difference } \\
\text { between both, is } \\
\text { about learning and } \\
\text { deepening sciences } \\
\text { that comes from } \\
\text { the Al-Qur'an and } \\
\text { Al-Hadith is wajib } \\
\text { 'ain (mandatory to } \\
\text { everyone). At the } \\
\text { same time, exploring } \\
\text { sciences that come } \\
\text { from humans is wajib } \\
\text { kifayah (mandatory } \\
\text { for some people). } \\
\text { However, the two } \\
\text { types of science from } \\
\text { different sources } \\
\text { must be learned } \\
\text { simultaneously. }\end{array}$ \\
\hline
\end{tabular}

Based on the paradigms and concepts as explained in the table 1 above, it can be seen that substantially, the concept of integration from each UIN actually has a similarity, which is to integrate religious and general science and eliminate the dichotomy between the two sciences.

As mentioned in the table, the concept of science integration in UIN Maulana Malik Ibrahim Malang refers to the scientific paradigm that is likened to a tree, which is called the "Tree of Science". Philosophically, the tree stands very sturdy and is leafy and fruitful because it is supported by strong roots. Strong roots not only serve to support the tree's trunk, but also absorb soil content for the tree's growth. The following is the picture of the tree of science developed at UIN Maulana Malik Ibrahim Malang.

Figure 1. The Tree of Science at UIN Maulana Malik Ibrahim Malang

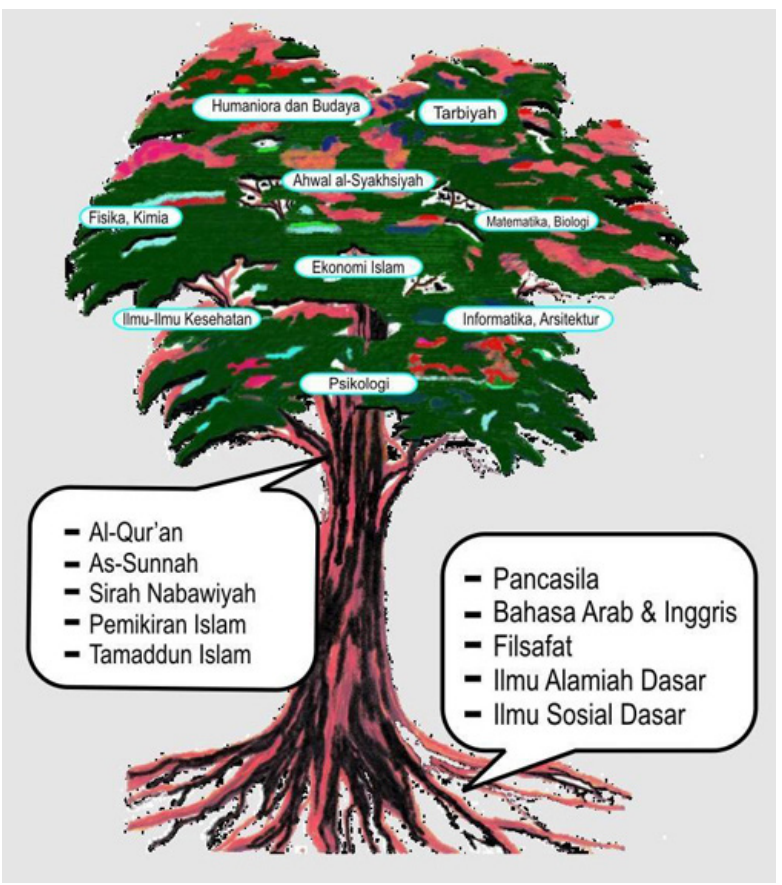

(Source: Profile of UIN Maulana Malik Ibrahim Malang, 2010)

Conceptually, the epistemology of the integration of religion and general science is the core idea of the institutional transformation from STAIN Malang into UIN Maulana Malik Ibrahim Malang with the concept of the tree of knowledge that was conceived and built by Imam Suprayogo. ${ }^{14}$ In the context of the tree of

${ }^{14}$ Imam Suprayogo, Membangun Integrasi Ilmu dan Agama. 
science, UIN Maulana Malik Ibarahim elaborates in more detail that the root of the tree represents the university's scientific foundation, which includes: (1) Arabic and English, (2) Philosophy, (3) Natural Sciences, (4) Social Sciences, and Pancasila and Civic Education. This knowing of scientific foundation is the basic capital for students to understand all aspects of Islamic sciences, which is described as the tree's trunk that becomes the identity of university students, there are: (1) Al-Qur'an and Al-Sunnah, (2) Sirah Nabawiyah, (3) Islamic Thought, and (4) Islamic Community Insight. Then, the branches and twigs represent the university's scientific fields which are constantly growing, including: (1) Tarbiyah, (2) Shari'ah, (3) Humanities and Culture, (4) Psychology, (5) Economics, and ( 6) Science and Technology. Flowers and fruit describe the output and outcomes, including; faith, piety, and being knowledgeable.

The distinctive paradigm and concept is developed by UIN Syarif Hidayatullah Jakarta. Although it has similarities in their scientific paradigms, the formulation of the concept of science integration at UIN Syarif Hidayatullah Jakarta is more open and leads to an integral paradigm. UIN Jakarta embraces the concept of the reintegration of sciences based on the paradigm of dialogic integration, open and critical paradigm, which is the open perspective of the science and respect proportionally for the existing types of science without leaving critical traits. ${ }^{15}$

In addition, the concept of science integration at UIN Jakarta has not been compiled perfectly, systematicaly, hierarchically, nor holisticaly as well as it has been formulated by UIN Maulana Malik Ibrahim Malang. However, UIN Syarif Hidayatullah, legally issued a Rector's Decree on December 27, 2017 regarding the

Pengalaman UIN Malang [Building Integration of Science and Religion. UIN Malang's Experience], in Haidar Bagir dan Zainal Abidin, (ed), Filsafat Sains Islami: Kenyataan atau Khayalan [Islamic Science Philosophy: Reality or Imagination], (Bandung: Mizan, 1990). See. Also. Asiyah, "Epistemologi Keilmuan Baru di Perguruan Tinggi Keagamaan Islam Negeri (Transformasi dari STAIN/IAIN Menjadi UIN)", Madania: Jurnal Kajian Keislaman, vol. 20, no.2 (December 2016), pp. 237- 238.

${ }^{15}$ Lalu Muhammad Nurul Wathan, Integrasi Pendidikan..., pp. 210.
Guidelines for Science integration in UIN Syarif Hidayatullah Jakarta. ${ }^{16}$ This Rector's Decree at least can be an indicator that factually UIN Jakarta already has official writen documents regarding the concept of science integration. However, the Rector's Decree has also not touched on the application of the concept of science integration. This condition makes the paradigm and the concept of science integration at UIN Jakarta still only at the philosophical and legal document level, so the stages of science integration application, at this university has not yet been founded.

To verify whether the paradigms and concepts in both universities are well- known by the lecturers and students, a questionnaire was distributed to students and lecturers in each campus. Based on the questionnaire results, the lecturers and students in each campus do not yet fully understand the paradigms and concepts of science integration. The development of the concept of science integration in both UINs, was not fully understood by the academics, especially the students. Based on the results of the tabulated questionnaires distributed to 480 students, 85.8 percent (412 students) did not understand the concepts and development of science integration, while only 14.2 percent (68 students) knew about the concepts and development of science integration. When looking at the students' understanding of the concept and development of science integration, it was found that there were 26 students at UIN Jakarta who knew about the concept of science integration on their campus and 219 students who did not know about it. Meanwhile, there were 42 UIN Malang students who knew about the concept of science integration on their campus and 193 students that did not understand the concept of science integration. More information can be seen in the table below.

${ }^{16}$ Look at the Rector 's Decree of UIN Syarif Hidayatullah Jakarta No 864 of 2017 on the Guidelines for Science integration in Syarif Hidayatullah Jakarta UIN, signed by Prof. Dr Dede Rosyada, MA. On the 27th of December 2017. The Decree stated that the integration of science is the fusion of Islamic religious knowledge with other sciences, so that science is not in conflict with and not dichotomous (Article 2, paragraph 1). 
Table 2. Student Knowledge on the Integration Concept in Each University

\begin{tabular}{ccccc}
\hline Count & \multicolumn{3}{c}{$\begin{array}{c}\text { Understanding of } \\
\text { science integration }\end{array}$} & Total \\
\cline { 2 - 4 } & \multicolumn{2}{c}{ Yes } & No & \\
\hline \multirow{2}{*}{ University } & $\begin{array}{l}\text { UIN Syarif } \\
\text { Hidayatullah Jakarta }\end{array}$ & 26 & 219 & 245 \\
\cline { 2 - 4 } & $\begin{array}{l}\text { UIN Maulana Malik } \\
\text { Ibrahim Malang }\end{array}$ & 42 & 193 & 235 \\
\hline & 68 & 412 & 480 \\
\hline
\end{tabular}

Different conditions were found when looking at the results obtained from the lecturers. Based on the results of the tabulated questionnaires that were distributed to 30 lecturers, 26.5 percent (22 lecturers) did not know about the concept and the development of science integration at UIN, while 73.5 percent (61 lecturers) knew about the concept and the development of science integration in each campus. The knowledge of the lecturers about the paradigm and the concept of science integration indicated that 56 lecturers at UIN Jakarta were aware, while two lecturers did not know about the concept of science integration on their campus. Additionally, at UIN Malang, there were five lecturers who knew and 20 lecturers that did not know about the concept of integration on their campus. More information can be seen in the table below.

Table 3. Lecturer Knowledge on the Integration Concept in Each University

\begin{tabular}{lllll}
\hline \multirow{2}{*}{ Count } & \multicolumn{3}{c}{$\begin{array}{l}\text { Understanding } \\
\text { of science } \\
\text { integration }\end{array}$} & Total \\
\cline { 2 - 4 } & \multicolumn{2}{c}{ Yes } & No & \\
\hline \multirow{2}{*}{ University } & $\begin{array}{l}\text { UIN Syarif } \\
\text { Hidayatullah Jakarta }\end{array}$ & 56 & 2 & 58 \\
\cline { 2 - 4 } & $\begin{array}{l}\text { UIN Maulana Malik } \\
\text { Ibrahim Malang }\end{array}$ & 5 & 20 & 25 \\
\hline & Total & 61 & 22 & 83 \\
\hline
\end{tabular}

Based on the two tables, it can be explained that the socialization of the paradigms and concepts development of science integration in each UIN is still a problem. The lack of socialization has implications that many students do not have a good knowledge about the paradigms and concepts of science integration on their campus.
This of course becomes very ironic, considering that the students are the subjects who receive the direct benefits from the development of the paradigm and the concept of science integration.

\section{Strategy and Implementation \\ 1. Strategy and Implementation of Integration of Science on Curriculum Design}

The following is an overview of the policies and strategies of each UIN in implementing the concept of science integration in curriculum design.

Table 4. The Policy and Implementation Strategy of Science Integration in Curriculum Design

\begin{tabular}{|c|c|c|c|}
\hline No. & $\begin{array}{l}\text { Name of } \\
\text { University }\end{array}$ & Policy & Strategy \\
\hline \multirow[t]{4}{*}{1} & \multirow[t]{4}{*}{$\begin{array}{l}\text { UIN Syarif } \\
\text { Hidayatullah } \\
\text { Jakarta }\end{array}$} & \multirow{4}{*}{$\begin{array}{l}\text { The policy } \\
\text { formulation of the } \\
\text { science integration } \\
\text { in curriculum design } \\
\text { at UIN Jakarta, in } \\
\text { fact there was no } \\
\text { specific document } \\
\text { found that described } \\
\text { the policies and } \\
\text { strategies of } \\
\text { science integration } \\
\text { in practicing the } \\
\text { concept on the } \\
\text { curriculum design. } \\
\text { The strategy of } \\
\text { science integration } \\
\text { can be found in } \\
\text { the Decree of } \\
\text { Rector of UIN Syarif } \\
\text { Hidayatullah Jakarta } \\
\text { No. } 864 \text { of } 2017 \text {, } \\
\text { Article } 6 \text {, Subsection } \\
1 \text { and } 2 \text {. }\end{array}$} & $\begin{array}{l}\text { a. Strengthening } \\
\text { of knowledge } \\
\text { relevant to the } \\
\text { Islamic religious } \\
\text { knowledge; }\end{array}$ \\
\hline & & & $\begin{array}{l}\text { b. Strengthening } \\
\text { Islamic religious } \\
\text { knowledge } \\
\text { for general } \\
\text { knowledges; }\end{array}$ \\
\hline & & & $\begin{array}{l}\text { c. The Establishment } \\
\text { of Ma'had Aly; }\end{array}$ \\
\hline & & & $\begin{array}{l}\text { d. The Establishment } \\
\text { of Institute for } \\
\text { Quality Assurance. }\end{array}$ \\
\hline \multirow[t]{8}{*}{2} & \multirow{8}{*}{$\begin{array}{l}\text { UIN } \\
\text { Maulana } \\
\text { Malik } \\
\text { Ibrahim } \\
\text { Malang }\end{array}$} & \multirow{8}{*}{$\begin{array}{l}\text { Curriculum design } \\
\text { is based on } \\
\text { Integration related } \\
\text { to four factors, } \\
\text { including; (1) } \\
\text { spiritual depth, (2) } \\
\text { moral greatness, } \\
\text { (3) comprehensive } \\
\text { of knowledge, and } \\
\text { (4) maturity, which } \\
\text { must be integrated } \\
\text { into five courses } \\
\text { groups, including; } \\
\text { Personality } \\
\text { Development } \\
\text { Courses (MPK), } \\
\text { Scientific and } \\
\text { Skills Courses } \\
\text { (MKK), Work Skills } \\
\text { Courses (MKB), } \\
\text { Work Behavior } \\
\text { Courses (MPB), and } \\
\text { Community Life } \\
\text { Courses (MBB) }\end{array}$} & $\begin{array}{l}\text { a. The Establishment } \\
\text { of Ma'had 'Ali; }\end{array}$ \\
\hline & & & $\begin{array}{l}\text { b. Creating Special } \\
\text { Program for } \\
\text { Arabic Language } \\
\text { Development } \\
\text { (PKPBA); }\end{array}$ \\
\hline & & & $\begin{array}{l}\text { c. Creating Special } \\
\text { Program for English } \\
\text { Development } \\
\text { (PKPBI); }\end{array}$ \\
\hline & & & $\begin{array}{l}\text { d. Writing of } \\
\text { Integrated } \\
\text { Textbooks for } \\
\text { Lecturers; }\end{array}$ \\
\hline & & & $\begin{array}{l}\text { e. Lecturer } \\
\text { Recruitment for } \\
\text { those who have } \\
\text { memorized the } \\
\text { Qur'an; }\end{array}$ \\
\hline & & & $\begin{array}{l}\text { f. Workshop for } \\
\text { Integrated } \\
\text { Curriculum; }\end{array}$ \\
\hline & & & $\begin{array}{l}\text { g. The Establishment } \\
\text { of Institute for al- } \\
\text { Qur'an and Science } \\
\text { Studies (LKQS); }\end{array}$ \\
\hline & & & $\begin{array}{l}\text { h. The Establishment } \\
\text { of Institute for } \\
\text { Quality Assurance. }\end{array}$ \\
\hline
\end{tabular}




\section{a. UIN Syarif Hidayatullah Jakarta}

Although no written documents were found regarding the policy at UIN Syarif Hidayatullah Jakarta of implementing the concept of science integration in the curriculum design, several faculties at UIN Syarif Hidayatullah Jakarta have tried to implement science integration in their curriculum design. UIN Jakarta has implemented the integration of science and religion by reconstructing syllabi and learning material. Without reducing the quality of natural sciencies courses studied by students, it should lead to improved results, because students will be increasingly convinced that Islam is a comprehensive religion and they will also have religious guidelines for their whole life. ${ }^{17}$ In addition, the implementation of science integration in the curriculum design, can also be observed from the inclusion of religious sciences in the learning process at the general faculties (faculties with non-religion studies).

Furthermore, the policy of curriculum development at UIN Syarif Hidayatullah Jakarta has implemented a curriculum based on the Indonesian National Qualification Framework (KKNI) since the Academic Year 2014/2015. The application of KKNI in this university was to fulfill the mandate of several educational regulations in Indonesia, including; (1) Constitution of the Republic of Indonesia Number 20 Year 2003 concerning National Education System; (2) Constitution of the Republic of Indonesia Number 12 of 2012 concerning Higher Education; (3) Government Regulation of the Republic of Indonesia Number 14 of 2014 concerning Management and Implementation of Education;

(4) Presidential Regulation Number 8 of 2012;

(5) Regulation of the Minister of Research, Technology and Higher Education Number 44 Year 2015 concerning National Standards for Higher Education; (6) Rector's Decree Number 10 of 2015; and (7) Amendment to the Rector Decree Number 215 of 2016 concerning Amendment to

17 Lalu Muhammad Nurul Wathan, Integrasi Pendidikan... ,p. 208. See. Azyumardi Azra, Membangun Integrasi Ilmu, Iman, Amal, dan Akhlak, dalam Proses Perubahan IAIN menjadi UIN: Rekaman Media Massa [Building on the integration of science, faith, compassion and morality in the process of transitioning IAIN to UIN: Mass Media Records], (Jakarta: UIN Jakarta Press, 2002)
Rector Decree Number 10 of 2015 concerning UIN Jakarta Curriculum Guidelines. ${ }^{18}$

Before the KKNI implementation, curriculum development at UIN Syarif Hidayatullah Jakarta referred to the Decree of the Minister of National Education (Kepmendiknas), Number: 232/U/ 2000 regarding Guidelines for the Preparation of Higher Education Curriculum and Assessment of Student Learning Outcomes, and referred to the Decree of the Minister of National Education (Kepmendiknas), Number: 045/U/ 2002 concerning the Higher Education Core Curriculum. Based on these two Decrees of the Minister of National Education, UIN Jakarta applies five principles in curriculum development, including; (1) Inventory of the professors opinions in their fields, the professional community and the user community by conducting various seminars and discussions; (2) Compile a book containing the scope and various issues including the method of presentation and then a discussion in terms of feasibility by several groups; (3) Train prospective lecturers who will present the intended courses; (4) Piloting at various universities; and (5) Discussing the pilot results and recommendations.

The curriculum design of all Study Programs at UIN Syarif Hidayatullah Jakarta, including bachelor, professional, master, and doctoral, has adopted the KKNI system, by prioritizing scientific specifications and applying science integration in each study program. The specifications of the study program remain in line with the formulation of the vision, mission, and objectives at the university and each faculty. The specifications of each study program are outlined in the study program outcomes and are reduced to program learning outcomes.

\section{b. UIN Maulana Malik Ibrahim Malang}

In the context of the implementation of the science integration concept in curriculum development, university leaders initiated an integration-based curriculum, which is technically divided into five groups, including; (1) Personality Development Courses (MPK); (2) Science and

18 Tim Penyusun, Pedoman Akademik Program Strata Satu UIN Syarif Hidayatullah Jakarta Tahun Akademik 2018/2019, (Jakarta: UIN Jakarta Press, 2018), pp. 67-68 
Skills Courses (MKK); (3) Work Skills Courses (MKB); (4) Work Behavior Course (MPB); and (5) Community Life Courses (MBB). Curriculum development is coordinated by the quality assurance institute by carrying out various activities to strengthen science integration for lecturers, such as integration-based curriculum workshops and training on science integration for lecturers. ${ }^{19}$

To verify whether the integrated curriculum is being applied or not, university leaders regularly evaluate the integrated curriculum that has been implemented, especially in the design and implementation of the syllabus and lesson plans (RPS). The evaluation and synchronization process of the curriculum is usually conducted once a year. The results of the curriculum evaluation will become a keystone for university leaders to enrich and reinforce the lecturers knowledge and skills in designing syllabuses and lesson plans. In the context of curriculum synchronization, the university leader also involves various stakeholders, the Ministry of Religious Affairs, education experties, social experties and other industry experts.

In addition, to strengthen the concept of science integration, UIN Malang also established the Center for the Study of Science and Islam Integration (PKSI) as a center for study and research for the integration of science and Islam in particular and Islamic studies in general. As a center for studies and research originating from the university, PKSI cannot be separated from the nature of the integration paradigm promoted by UIN Malang, that is a scientific-religious society formation with inherent personality identities, namely spirituality profound, morality greatness, knowledge spaciousness, and professional perfection. Several programs have been planned by this institution, for example; studies and research related to the integrated curriculum and learning process, seminars/workshops, education and training for the junior and the senior lecturers to gain an equal understanding about the perspective of science integration and it's implementation in each department/study program, advocation and publication, as well

${ }^{19}$ Husniyatus Salamah Zainiyati, "Desain Pengembangan Kurikulum Integratif." Nadwa, vol. 8, no. 2 (2014): 295-312. as the development and empowerment of the scientific and religious communities.

To examine the implementation of science integration in the curriculum development, a crosscheck was made to the lecturers through the distribution of questionnaires, especially on two curriculum components, including; syllabus and RPS development. Based on the the tabulation results from the lecturer, it was found that 59 percent of the lecturers in both UINs stated that they considered the concept of science integration in the development of the syllabus. And 41.7 percent of the lecturers stated that they did not consider science integration in the development of the syllabus. In UIN Syarif Hidayatullah Jakarta there were 36 lecturers who considered integration in syllabus development and 22 lecturers who did not consider science integration in syllabus development. While at UIN Maulana Malik Ibrahim Malang there were 13 lecturers who considered the science integration in syllabus development and 12 lecturers who did not consider science integration in syllabus development. More information can be seen in the table below.

Table 5. Crosstabulation of Science integration Implementation on Syllaby Designed by Lecturers

\begin{tabular}{llccc}
\hline Count & \multicolumn{3}{c}{$\begin{array}{c}\text { Considering Science } \\
\text { integration on } \\
\text { Syllaby }\end{array}$} & Total \\
\cline { 2 - 5 } & \multicolumn{2}{c}{ Yes } & No & \\
\hline \multirow{2}{*}{ University } & $\begin{array}{l}\text { UIN Syarif } \\
\text { Hidayatullah Jakarta }\end{array}$ & 36 & 22 & 58 \\
\cline { 2 - 5 } & $\begin{array}{l}\text { UIN Maulana Malik } \\
\text { Ibrahim Malang }\end{array}$ & 13 & 12 & 25 \\
\hline Total & 49 & 34 & 83 \\
\hline
\end{tabular}

Different results were found in the development of RPS. The majority of lecturers did not carry out science integration in the development of RPS. This can be seen from the data tabulation results which illustrated that 39.8 percent of lecturers stated that they included science integration in the development of RPS. And 60.2 percent of lecturers stated that they carried out science integration in the development of RPS. The results obtained from UIN Syarif Hidayatullah Jakarta showed that there were 25 lecturers who considered science integration in the development of RPS and 33 lecturers who did not 
consider science integration in RPS development. Meanwhile, at UIN Maulana Malik Ibrahim there were eight lecturers who considered science integration in the development of RPS and 17 lecturers who did not consider science integration in the development of RPS.

Table 6. Crosstabulation of the Science integration Implementation on Lesson Plan Designed by the Lecturers

\begin{tabular}{lllll}
\hline Count & \multicolumn{3}{c}{$\begin{array}{c}\text { Integration } \\
\text { considered in } \\
\text { lesson plan design }\end{array}$} & Total \\
\cline { 3 - 4 } & & Yes & No & \\
\hline \multirow{2}{*}{ University } & $\begin{array}{l}\text { UIN Syarif } \\
\text { Hidayatulla Jakarta }\end{array}$ & 25 & 33 & 58 \\
\cline { 2 - 3 } & $\begin{array}{l}\text { UIN Maulana Malik } \\
\text { Ibrahim Malang }\end{array}$ & 8 & 17 & 25 \\
\hline & Total & 33 & 50 & 83 \\
\hline
\end{tabular}

\section{Strategy and Implementation of Science integration on Learning Management}

In the context of the implementation of science integration in this learning management, it can be explained that the two UINs that were the sample of the study had implemented the learning process based on the science integration. However, UIN Maulana Malik Ibrahim Malang appeared to have a more extensive implementation than the implementation strategy at UIN Syarif Hidayatullah Jakarta. The following is an overview of the policies and strategies for implementing science integration in the learning management in each university.

Referring to the table, it can be seen that both universities have written policies regarding the implementation of science integration in the learning documents. On the Guidelines for the Development of the Lesson Plans (Pedoman Pengembangan Rencana Perkuliahan Semester [RPS]) issued by the Institue for Quality Assurance (LPM) UIN Syarif Hidayatullah Jakarta, it is written that the RPS should include an Integration component on three areas; science integration, Indonesian-ness integration and Islamic integration. Science integration refers to the relations of the courses with other sciences/disciplines. If the courses are a general category, the lecturer must state their relationship with religious knowledge. Meanwhile the Indonesian-ness integration is to write the relationship between the courses with the nationalism issues and Indonesian contexts. Whereas the Islamic integration is the relationship between the courses with Islamic values that must be linked to every learning material and in every learning process.

Table 7. Policies and Strategies of Science integration in Learning Management

\begin{tabular}{|c|c|c|c|}
\hline No. & $\begin{array}{l}\text { Name of } \\
\text { University }\end{array}$ & Policy & Strategy \\
\hline 1 & $\begin{array}{l}\text { UIN Syarif } \\
\text { Hidayatullah } \\
\text { Jakarta }\end{array}$ & $\begin{array}{l}\text { The learning process } \\
\text { refers to four } \\
\text { main components } \\
\text { that affect quality } \\
\text { products, including: } \\
\text { Input, Process, } \\
\text { Output, and } \\
\text { Outcome. To get } \\
\text { the best "input", } \\
\text { the admission of } \\
\text { each new student } \\
\text { is conducted using } \\
\text { a strict selection } \\
\text { system. Meanwhile, } \\
\text { the factors that } \\
\text { support the the } \\
\text { quality of learning } \\
\text { in the "process" } \\
\text { component are the } \\
\text { learning material } \\
\text { being studied, } \\
\text { learning resources, } \\
\text { evaluation of the } \\
\text { process and learning } \\
\text { outcomes. All of that } \\
\text { is outlined in the } \\
\text { form of curriculum/ } \\
\text { RPS documents } \\
\text { and implemented } \\
\text { in learning process. } \\
\text { Therefore, the RPS } \\
\text { should at least } \\
\text { contain components } \\
\text { of Learning } \\
\text { Achievements, } \\
\text { Learning Materials, } \\
\text { Strategies, Media, } \\
\text { Methods, Integration } \\
\text { (Scientific, } \\
\text { Indonesian-ness and } \\
\text { Islam), evaluation, } \\
\text { time and reference. }\end{array}$ & $\begin{array}{l}\text { a. RPS refers to the } \\
\text { format designed } \\
\text { by the university } \\
\text { leaders to include } \\
\text { integration } \\
\text { components; } \\
\text { scientific, Islamic } \\
\text { and Indonesian- } \\
\text { ness integration; } \\
\text { b. Written Textbooks } \\
\text { have to based } \\
\text { on Science } \\
\text { integration; } \\
\text { c. Grants for } \\
\text { Research Based } \\
\text { on Science } \\
\text { integration; } \\
\text { d. Scholarships for } \\
\text { PhD Students. }\end{array}$ \\
\hline 2 & $\begin{array}{l}\text { UIN Maulana } \\
\text { Malik Ibrahim } \\
\text { Malang }\end{array}$ & $\begin{array}{l}\text { The learning } \\
\text { process refers to an } \\
\text { integration-based } \\
\text { curriculum that is } \\
\text { based on the vision, } \\
\text { mission, goals and } \\
\text { the "Tree of Science" } \\
\text { paradigm that was } \\
\text { appointed by UIN } \\
\text { Malang. In addition, } \\
\text { the university } \\
\text { leader carries out } \\
\text { monitoring and } \\
\text { evaluation for the } \\
\text { implementation of } \\
\text { science integration } \\
\text { to the development } \\
\text { of curriculum and } \\
\text { the learning process, } \\
\text { that's known as: } \\
\text { "Universitas Kejar } \\
\text { Fakultas" }\end{array}$ & $\begin{array}{l}\text { a. Scholarship for } \\
40 \text { PhD Students } \\
\text { every year; } \\
\text { b. Written Textbooks } \\
\text { refering to the } \\
\text { science integration } \\
\text { paradigm as } \\
\text { outlined in } \\
\text { "The Tree of } \\
\text { Knowledge". } \\
\text { c. Designing } \\
\text { Integrated-RPS; } \\
\text { d. Habituating in } \\
\text { integrated-thesis } \\
\text { writing. }\end{array}$ \\
\hline
\end{tabular}


Besides the RPS formulation that has included science integration components, UIN Syarif Hidayatullah Jakarta through Rector's Decree Number 864 of 2017 has also confirmed that lecturers have to conduct science integration. Article 13 about Lecturer Responsibility states that lecturers have a responsibility to attempt the science integration in (1) learning process, (2) assignments to students, (3) writing scientific papers, (4) conducting research, and (5) community service.

In the context of strengthening human resources (lecturers) who are expected to be able to implement the concept of science integration in the learning process, the university leader of UIN Jakarta takes a strategy to provide scholarships for those lecturers who are completing their PhD programs. In addition, as part of strengthening the learning process quality, lecturers are also given the opportunity to acquire a grant for writing textbooks and research on science integration every year, which is carried out both selectively and competitively.

The same activities were also executed by UIN Maulana Malik Ibrahim, Malang. The university has policies and strategies in implementing science integration in the learning process, including the RPS design, learning process, thesis writing, taking on practicum (PKL) and lecturer recruitment. To ensure the suitability of the integration of science and the vision and mission of the university, the faculties and departments designate two thesis supervisors; a scientific supervisor, and also a religious integration supervisor. Aside from the thesis supervisors, thesis titles in any faculty must be based on science integration, because this is also emphasized in the thesis writing guidelines at the university.

In the context of the Field Work Practicum $(\mathrm{PKL})$, the implementation of science integration is also applied. For example, if students from the Departement of Biology take on practicum, then their activities are designed to combine their scientific disciplines with religious values. More technically, if in the morning students are working at a research center or conducting research on food crops, then in the afternoon the student will undertake community services, which is usually related to religious content.

The implementation of science integration is also applied in the recruitment and coaching of lecturers. At the beginning of the lecturers recruitment, they are tested about the Al-Qur'an and their memorization, and also interviews are conducted about their general knowledge of religion (Islam). If there are lecturers who do not have satisfactory results, the university leader will not provide a Letter of Appointment to the lecturer and they must take a course in reading and memorizing the Qur'an before they will be considered again.

In the context of the RPS design and the implementation of the learning process, the concept of science integration is also of particular concern in this section. For example, students at the Faculty of Science and Technology are given Al-Qur'an Studies courses, which certainly have different contents from the Al-Qur'an studies content for the students of the Faculty of Sharia and Law. Al-Qur'an Studies courses for students at Faculty of Science and Technology are placed as a foundation/platform in exploring the verses of kauniyah that are scattered across the universe. In other words, the learning material given to students of Faculty of Science and Technology is focused on verses about God's authority, the process of human creation, health, reproduction, environment and others which do not rule out the basic material on monotheism/Islamic monotheism.

To examine the policy and strategy for the implementation of science integration in the learning process, whether it is applied or not, cross-checks were conducted with lecturers and students through the distribution of questionnaires to 83 lecturers and 480 students at both UINs. The results indicated that the majority of lecturers consider the implementation and are very good at implementing science integration in the learning process. This can be seen from the scoring of the lecturer questionnaire result which shows 67 percent are "very good" in applying science integration, 20 percent are "good" and only 13 percent are sufficient in applying science integration, and not one lecturer responded and 
said that they have never conducted science integration in the learning process.

However, these results are only based on the questionnaires provided to the lecturers themselves, when compared with the students evaluation of their activities in the implementation of science integration in the learning process, there are rather different results. Based on the student questionnaire tabulation results, it was found that the majority of students considered that the lecturer was included in the "Good" category (64.23 percent) in integrating science into the learning process. While lecturers who are in the category of "Very Good" in implementing the concept of science integration in the learning process was 17.34 percent. The others are categorized as lecturers with the title "Sufficient" (17.07 percent), and there was even 1.36 percent of the lecturers who were considered as never doing the Science Integration in class in their learning process.

Therefore, based on the tabulation results of the questionnaires distribution given to students and lecturers at both UINs, it can be explained that the implementation of science integration in the learning process has been relatively applied by lecturers and students in their learning activities. However, there are some learning areas that have not been included into the science integration, for example the aspect of socializing the concept of science integration to students and the ability to connect religious content with general content etc.

\section{Conclusion}

Substantively, the two State Islamic Universities (UIN) have similar concepts of science integration and also have nearly the same goal, which is to remove the dichotomy of science, between religious and general sciences. However, at the level of implementation, both have different policies, strategies and have the different practices. This difference is based on academic studies in each university, university environment and when compared between UIN Syarif Hidayatullah Jakarta and UIN Maulana Malik Ibrahim Malang, UIN Maulana Malik Ibrahim Malang is considered more systematic in formulating the concept of science integration, starting from the philosophical-paradigm to the practice of the curriculum design and learning process.

\section{References}

Abdullah, M. Amin, "Religion, science and culture: An integrated, interconnected paradigm of science." Al-Jami'ah, vol. 52, no 1,2014, https:// doi.org/10.14421/ajis.2014.521.175-203

Al-Faruqi, Isma'il Razi, Al-Tauhid: Its Implications for Thought and Life, The International Institute of Islamic Thought, Virginia-USA, 1992.

Azra, Azyumardi, Pendidikan Islam: Tradisi dan Modernisasi Menuju Milenium Baru [Islamic Education: Tradition and Modernisation In the New Millennium], Jakarta: Logos Wacana Ilmu, 2002.

, Membangun Integrasi Ilmu, Iman, Amal, dan Akhlak, dalam Proses Perubahan IAIN menjadi UIN: Rekaman Media Massa [Building on the integration of science, faith, compassion and morality in the process of transitioning IAIN to UIN: Mass Media Records], Jakarta: UIN Jakarta Press, 2002

Asiyah, "Epistemologi Keilmuan Baru di Perguruan Tinggi Keagamaan Islam Negeri (Transformasi dari STAIN/IAIN Menjadi UIN)", Madania: Jurnal Kajian Keislaman, vol. 20, no.2, December 2016.

Aminuddin, Luthfi Hadi, INTEGRASI ILMU DAN AGAMA: Studi Atas Paradigma Integratif Interkonektif UIN Sunan Kalijaga Yogjakarta, Kodifikasia, vol.4, no.1, 2010.

Hanifah, Umi "Islamisasi Ilmu Pengetahuan Kontemporer (Konsep Integrasi Keilmuan di Universitas-Universitas Islam Indonesia)", Tadris, vol. 13, no. 2, Desember 2018. https:// doi.org/10.19105/tjpi.v13i2.1972 , "UPAYA INTEGRASI DIKOTOMI SISTEM PENDIDIKAN ISLAM (Telaah Terhadap Islamisasi IImu Pengetahuan dalam Transformasi IAIN Menuju UIN)". At-Tajdid: Jurnal Ilmu Tarbiyah, vol. 1, no. 1, 2012.

Hidayatullah, Syarif, "Islamisasi IImu dalam Perspektif Filsafat Ilmu." Jurnal Filsafat, vol. 23, no.3, 2013.

Jamal, Nur, "Model-Model Integrasi Keilmuan Perguruan Tinggi Keagamaan Islam” KABILAH: 
Journal of Social Community, vol.2, no. 1, October 13, 2017. http://ejournal.kopertais4.or.id/madura/ index.php/kabilah/article/view/3088

Kertanegara, Mulyadi Integrasi Ilmu: sebuah Rekonstruksi Holistik, Bandung: Arasy, 2005, First Edition

Muhaimin, Arah Baru Pengembangan Pendidikan I slam; Pemberdayaan, Pengembangan Kurikulum, hingga Redefinisi Islamisasi Pengetahuan, Bandung: Penerbit Nuansa, 2003.

Nurlena Rifa'i, et.al., “Integrasi Keilmuan dalam Pengembangan Kurikulum di UIN seIndonesia", TARBIYA: Jurnal of Education in Muslim Society, vol. 1, no. 1, June 2014.

Nata, Abuddin et.al., Integrasi Ilmu Agama dan Ilmu Umum, Jakarta: PT. Raja Grafindo Persada, 2005, First Edition.

Kuntowijoyo, Islam Sebagai Ilmu: Epistimologi, Metodologi dan Etika, Yogyakarta: Tiara Wacana, 2007.

Siregar, Parluhutan, "Integrasi Ilmu-Ilmu Keislaman Dalam Perspektif M.Amin Abdullah.” MIQOT: Jurnal Ilmu-IImu Keislaman. Vol. XXXVIII No. 2 Juli-Desember 2014.

Suprayogo, Imam, Membangun Integrasi Ilmu dan Agama. Pengalaman UIN Malang [Building Integration of Science and Religion. UIN Malang's Experience], in Haidar Bagir dan Zainal Abidin, (ed), Filsafat Sains Islami: Kenyataan atau Khayalan [Islamic Science Philosophy: Reality or Imagination], Bandung: Mizan, 1990

The Rector 's Decree of UIN Syarif Hidayatullah Jakarta No 864 of 2017 on the Guidelines for Science integration in Syarif Hidayatullah Jakarta UIN, signed by Prof. Dr Dede Rosyada, MA. On the 27th of December 2017, (Article 2, paragraph 1).

Tim Penyusun, Pedoman Akademik Program Strata Satu UIN Syarif Hidayatullah Jakarta Tahun Akademik 2018/2019, Jakarta: UIN Jakarta Press, 2018.

Undang-undang RI Nomor 20 Tahun 2003 tentang Sistem Pendidikan Nasional [Republic of Indonesia Act No. 20 of 2003 on the National Education Policy]

Wathan, Lalu Muhammad Nurul, Integrasi Pendidikan Islam dan Sains: Rekonstruksi Paradigma Pendidikan Islam, Ponorogo: CV. Uwais Inspirasi Indonesia, 2018.

Wiranata, Rz Ricky Satria. “Jalan Tengah: Kritik Paradigma Pendidikan di Barat (Sebuah Kajian Filosofis Historis)." Al-Misbah (Jurnal Islamic Studies),vol. 8, no. 2, 2020.

Zainiyati, Husniyatus Salamah. "Desain Pengembangan Kurikulum Integratif." Nadwa, vol. 8, no. 2, 2014. 